\title{
Cereal supplementation modified the fibrolytic activity but not the structure of the cellulolytic bacterial community associated with rumen solid digesta
}

\author{
Cécile MARTiN ${ }^{\mathrm{a} *}$, Liliane MiLleT ${ }^{\mathrm{b} * *}$, Gérard FonTY $^{\mathrm{b}}$, \\ Brigitte MichaLET-DOREAU ${ }^{\mathrm{a}}$ \\ a Unité de Recherche sur les Herbivores, INRA, Centre de Clermont-Theix, \\ 63122 Saint-Genès-Champanelle, France \\ b Unité de Microbiologie, INRA, Centre de Clermont-Theix, \\ 63122 Saint-Genès-Champanelle, France
}

(Received 30 July 2001; accepted 26 October 2001)

\begin{abstract}
-4 ruminally cannulated cows were fed a forage diet (93\% hay $+7 \%$ straw) and a mixed $\operatorname{diet}(33 \%$ hay $+7 \%$ straw $+40 \%$ barley) in a $2 \times 2$ crossover experimental design. In sacco degradation of forage, fibrolytic activities (polysaccharidases and glycosidases) of the solid-associated bacteria (SAB), and distribution of the 3 main cellulolytic bacterial species (Fibrobacter succinogenes, Ruminococcus albus, Ruminococcus flavefaciens) were determined for both diets. Barley supplementation decreased the hay degradation rate and mainly the polysaccharidase activities of the SAB (30\% on average). The sum of rRNA of the 3 cellulolytic bacterial species represented on average $17 \%$ of the total bacterial signal and $R$. albus was the dominant cellulolytic bacterial species of the 3 studied. Barley supplementation did not modify the proportion of the 3 cellulolytic bacteria attached to plant particles. The negative effect of barley on the ruminal hay degradation rate is due to a decrease in fibrolytic activity of the SAB, and not to a modification of the balance of the three cellulolytic bacterial species examined.
\end{abstract}

fibrolytic activity / oligonucleotide probe / cellulolytic bacteria / cereal supplementation / rumen

Résumé - La supplémentation en céréale modifie l'activité fibrolytique mais pas la structure de la communauté bactérienne cellulolytique associée à la phase solide du contenu ruminal. 4 vaches, canulées du rumen, ont été alimentées avec un régime fourrage (93\% foin $+7 \%$ paille) et un régime mixte (33\% foin $+7 \%$ paille $+60 \%$ orge) dans un schéma croisé $2 \times 2$. La dégradation

\footnotetext{
* Correspondence and reprints

E-mail: cecile@clermont.inra.fr

** Present address: Laboratoire de Recherche Fromagères, INRA, 36 rue de Salers, 15000 Aurillac, France.
} 
en sachet du foin, les activités fibrolytiques des bactéries associées à la phase solide (SAB), et la distribution des 3 principales espèces bactériennes cellulolytiques (Fibrobacter succinogenes, Ruminococcus albus, Ruminococcus flavefaciens) ont été déterminées pour chaque régime. La supplémentation en orge diminuait la vitesse de dégradation du foin et essentiellement les activités polyosidasiques des SAB (30\% en moyenne). La population des 3 espèces bactériennes cellulolytiques représentait en moyenne $17 \%$ de l'ARN bactérien total, et $R$. albus était l'espèce cellulolytique dominante parmi les 3 espèces étudiées. L'apport d'orge dans la ration ne modifiait pas la proportion des 3 espèces cellulolytiques attachées aux particules végétales. L'effet dépressif de l'orge sur la vitesse de dégradation du foin s'explique par une diminution de l'activité fibrolytique des SAB, et non par une modification de l'équilibre des trois espèces bactériennes cellulolytiques étudiées.

activité fibrolytique / sonde oligonucléotidique / bactérie cellulolytique / supplémentation en céréale / rumen

\section{INTRODUCTION}

The supplementation of forage diets with readily fermentable carbohydrates (RFC) is known to depress ruminal fibre digestion. At a constant feeding level, this depression is not due to a modification in the ruminal particulate passage rate but rather to a decrease in the fiber degradation rate [14]. Different studies $[5,18]$ have related the negative effect of RFC on fiber degradation rate to a decrease in fibrolytic activity of the solid-associated bacteria (SAB), which is considered to be the most active microbial population in plant cell wall degradation. However, it can be supposed that RFC supplementation alters the colonization of plant material by cellulolytic bacteria [11, 29]. Therefore, the origin of the fibrolytic activity decrease in the SAB involved by RFC remains unknown. A specific decrease in the fibrolytic activity of the SAB and/or a modification in the repartition (number, species) of the cellulolytic bacteria colonizing the plant material may be supposed. The purpose of the experiment was to investigate the effect of barley supplementation on ruminal fiber digestion in relation to changes in the fibrolytic activity and structure of the solid phase-attached cellulolytic bacterial community. The originality of this work was to use the oligonucleotide probes to quantify 3 cellulolytic bacterial species (Fibrobacter succinogenes, Ruminococcus flavefaciens, Ruminococcus albus) in the rumen microbial communities. These cellulolytic bacteria were chosen because of their importance in the ruminal ecosystem and because of the availability of well-characterized species-specific oligonucleotide probes [19].

\section{MATERIALS AND METHODS}

\subsection{Experimental design, animals and feeding}

4 adult dry Jersey cows (average BW 528 $\pm 57 \mathrm{~kg}$ ) received two successive diets in a $2 \times 2$ crossover experimental design. The first diet was $93 \%$ unchopped Cocksfoot hay (Dactylis glomerata second cutting) and $7 \%$ wheat-straw on a DM basis ( $\mathrm{H}$ diet). The second diet was $33 \%$ and $7 \%$ of the same hay and straw, respectively, and $60 \%$ pelleted ground barley (3-mm screen) (HB diet). The chemical compositions of experimental feeds and diets are given in Table I. Feed availability was restricted $(80 \%$ of ad libitum intake) at the level of $7 \mathrm{~kg}$ of DM per day to ensure that the diet was ingested quickly and without refusals. The animals received their ration in two equal portions at 08:00 $\mathrm{h}$ and 20:00 $\mathrm{h}$.

All animals were fitted with permanent ruminal cannulas made of polyamide and polyvinyl chloride (Synthesia, Nogent-sur- 
Table I. Chemical composition of experimental feeds and diets.

\begin{tabular}{lrrrc}
\hline Item & OM & CP & $\begin{array}{c}\text { Crude } \\
\text { fiber }\end{array}$ & Starch \\
\cline { 2 - 5 } & \multicolumn{5}{c}{$\%$ DM } \\
\hline Feeds & & & & \\
$\quad$ Hay & 93.4 & 14.8 & 32.4 & - \\
$\quad$ Straw & 91.1 & 3.0 & 40.1 & - \\
$\quad$ Barley & 96.6 & 11.6 & 5.9 & 57.0 \\
Diets & & & & \\
93\% hay $+7 \%$ straw & 93.3 & 14.0 & 32.9 & - \\
33\% hay $+7 \%$ straw $+60 \%$ barley & 95.2 & 12.1 & 17.0 & 34.2 \\
\hline
\end{tabular}

Marne, France) and were used as donor animals for rumen digesta. Surgery was performed in a sterile environment under general anesthesia (isofluorane; ICIU Pharma-vétérinaire, Paris, France). Cows received antibiotic treatments for $4 \mathrm{~d}$ after surgery. They were housed in individual metabolism cages in an air-conditioned and continuously lit room, with free access to water and mineralized salt blocks $(38 \% \mathrm{~N}$, $0.9 \% \mathrm{Zn}, 0.075 \% \mathrm{Mn}, 0.15 \mathrm{Cu}, 0.009 \% \mathrm{I}$, and $0.0003 \% \mathrm{Co}$ ).

Six-week adaptation periods were allowed for each diet followed by two-week measurement periods.

\subsection{In situ forage degradation}

The hay DM degradation rate in the rumen was measured for each dietary treatment by the in situ technique. Polyester bags (Ankom Co, Fairport, NY, USA; pore size: $53 \mu \mathrm{m}$; internal dimensions: $5 \times 10 \mathrm{~cm}$ ) were dried $\left(80^{\circ} \mathrm{C}\right.$ for $24 \mathrm{~h}$ ), weighed, filled with $3 \mathrm{~g}$ of ground hay (sieve size $3 \mathrm{~mm}$ ), and introduced in the rumen just before morning feeding for 2, 4, 8, 16, 24, 48 and $72 \mathrm{~h}$. There were two replicate bags for each incubation time. The bags were rinsed in a washing machine with 3 successive 2 -min washings, dried $\left(80{ }^{\circ} \mathrm{C}\right.$ for $\left.48 \mathrm{~h}\right)$, and weighed. The DM degradation kinetics, representing those of plant cell walls, were fitted to an exponential model with lag time [3]:

$$
D(t)=a+b\left(1-e^{-c(t-\theta)}\right),
$$

where $D(t)$ is the percentage disappearance from the bag at time $t$, of the rapidly $(a)$ and slowly (b) degradable fraction, $c$ is the constant rate of degradation of $b$, and $\theta$ the lag time before degradation began. Effective degradability was calculated using the particle outflow rate of $0.06 \mathrm{~h}^{-1}$ [28].

\subsection{Sample collection, ruminal $\mathrm{pH}$ measurements and separation of solid-associated bacteria}

Samples of ruminal digesta $(1 \mathrm{~kg})$, as a mix of liquid and solid phase, were manually taken from the ventral sac of the rumen via the cannula in a capped plastic container to minimize oxygen contact. For each animal, the samples were collected prior $(-1 \mathrm{~h})$ and after $(+3 \mathrm{~h})$ the a.m. feeding on two sampling days with a 2-day interval to avoid possible disturbance of ruminal function. Collection of ruminal contents was duplicated for each animal on two consecutive weeks.

A portion $(50 \mathrm{~g})$ of the rumen contents was immediately strained through a $100-\mu \mathrm{m}$ nylon filter and the ruminal juices were then 
maintained under magnetic stirring for the measurement of $\mathrm{pH}$ with a digital $\mathrm{pH}$-meter CG840 (Ag/AgCl electrode).

The second portion of rumen contents were rapidly transported to the laboratory for separation of the solid-associated microbial population under anaerobic conditions. Samples were strained through a $100-\mu \mathrm{m}$ nylon filter to separate a solid phase (SP). Samples of SP (70 g) were washed with $350 \mathrm{~mL}$ salt solution prewarmed at $39^{\circ} \mathrm{C}$ to remove the non-adherent and looselyadherent microbial populations and then recovered by filtration $(100 \mu \mathrm{m})$, and the washed digesta containing solid-associated bacteria $(\mathrm{SAB})$ were then fractionated into 3 parts. A first sample ( $5 \mathrm{~g})$ was cut to $<0.5 \mathrm{~cm}$ lengths and suspended in $25 \mathrm{~mL}$ of anaerobic buffer $(0.025 \mathrm{M} 2$-(N-morpholino)ethane-sulphonic acid [MES], $\mathrm{pH} 6.5,4^{\circ} \mathrm{C}$ ) containing $1 \mathrm{mM}$ DL-dithiothreitol (DTT) and stored at $-80{ }^{\circ} \mathrm{C}$ before enzyme activity measurements. A second sample (30 g) was freeze-dried for quantification of the bacterial cellulolytic community and the remaining of washed digesta was used for dry matter content determination $\left(48 \mathrm{~h}\right.$ at $\left.80^{\circ} \mathrm{C}\right)$.

\subsection{Enzyme preparation and fibrolytic activity measurement}

Enzyme extraction from the SAB was performed under anaerobic conditions by the method detailed by Martin and MichaletDoreau [13]. SAB were broken by defrosting and ultrasonic disintegration with an MSE Soniprep 150 disintegrator (MSE instruments, Crawley) to release intracellular enzymes. Samples were sonicated for four 30-s periods with 30-s intervals at $4{ }^{\circ} \mathrm{C}$ under anaerobic conditions. Unbroken cell material was removed by centrifugation $\left(15000 \mathrm{~g}, 15 \mathrm{~min}, 4^{\circ} \mathrm{C}\right)$, and the supernatant material was used to estimate polysaccharide depolymerase and glycoside hydrolase activities in the SAB. Enzyme preparations were stored under a $\mathrm{CO}_{2}$ headspace in capped tubes at $-80{ }^{\circ} \mathrm{C}$ before assay.

Fibrolytic activities (polysaccharidases and glycosidases) were measured using the assay detailed by Martin et al. [15]. Polysaccharidase activities were determined by measuring the amount of reducing sugars released from purified substrates (Birchwood-xylan, Sigma X-0502; carboxymethylcellulose (CMC), Sigma C-5678) after incubation of the substrate with the enzyme preparation at $39^{\circ} \mathrm{C}$ for $60 \mathrm{~min}$. Xylan and CMC $\left(2 \mathrm{mg} \cdot \mathrm{mL}^{-1}\right)$ were prepared in MES buffer $(0.025 \mathrm{M}, \mathrm{pH}$ 6.5) and incubated $(1.0 \mathrm{~mL})$ with the enzyme preparation $(0.1 \mathrm{~mL})$. The reaction was stopped by denaturating enzyme proteins (heating at $100{ }^{\circ} \mathrm{C}$ for $5 \mathrm{~min}$ ). Reducing sugars were quantified spectrophotometrically at $410 \mathrm{~nm}$ [9].

Glycosidase activities were determined by measuring the amount of $p$-nitrophenol released from the appropriate $p$-nitrophenyl glycoside (Sigma, $p$-nitrophenyl- $\beta$-Dxylopyranoside $\mathrm{N}-1232$, $-\alpha$-L-arabinofuranoside N-3641, - $\beta$-D-glucopyranoside $\mathrm{N}-7006 ; 5 \mathrm{mM}$ in MES buffer $0.025 \mathrm{M}$, $\mathrm{pH}$ 6.5) after incubation of $1.0 \mathrm{~mL}$ substrate with $0.1 \mathrm{~mL}$ enzyme preparation at $39^{\circ} \mathrm{C}$ for 15 to $60 \mathrm{~min}$. The reaction was stopped by addition of $1.1 \mathrm{~mL}$ glycine- $\mathrm{NaOH}$ solution $\left(0.4\right.$ mol glycine $\left.\cdot \mathrm{L}^{-1}, \mathrm{pH} 10.8\right)$. The released $p$-nitrophenol was quantified spectrophotometrically at $420 \mathrm{~nm}$.

Enzyme and substrate controls were also performed simultaneously by replacing substrate and enzymes by the MES buffer, respectively. The protein content of the enzyme preparations was determined according to Pierce and Suelter [20] using bovine serum albumin as the standard. Enzyme activities were expressed as the quantity of reducing sugar (for polysaccharidases) or $p$-nitrophenol (for glycosidases) released per mg protein per $1 \mathrm{~h}$ for specific activity or $\mathrm{g}$ DM solid phase per $1 \mathrm{~h}$ for total activity. 


\subsection{Quantification of the cellulolytic bacterial species}

Selected cellulolytic bacterial species were quantified using specific 16S-rRNAtargeting probes. RNA was extracted from $50 \mathrm{mg}$ of a freeze-dried sample by mechanical disruption of microorganisms for $2 \mathrm{~min}$ in a reciprocating shaker (MM2000, Kurt Retsch, 42781 Haam, Germany) with zirconium beads (diameter $0.1 \mathrm{~mm}$ ). Samples were processed in conical screw-capped propylene vials. Each vial contained the freeze dried rumen content, $1 \mathrm{~mL}$ of RNAzol (Bioprobe Systems, 93100 Montreuil, France) and $0.1 \mathrm{~g}$ of zirconium beads. RNAzol contained guanidium thiocyanate (4 M) and phenol ( $\mathrm{pH}$ 7.5). Mechanical disruption insured uniform extraction of nucleic acids from gram-positive, gram-negative and eucaryote microorganisms [24]. After shaking, the vials were heated at $100{ }^{\circ} \mathrm{C}$ for $2 \mathrm{~min}$, and centrifuged (14000 $\mathrm{g}$ for $20 \mathrm{~min}$ ). After two extractions with an equal volume of $\mathrm{CHCl}_{3}$, RNA was recovered by isopropanol precipitation $\left(30 \mathrm{~min}\right.$ at $-20{ }^{\circ} \mathrm{C}$ ) and centrifugation (14000 $\mathrm{g}$ for $30 \mathrm{~min}$ ). The pellet was then rinsed with $200 \mu \mathrm{L}$ of ethanol $75 \%$, and centrifuged (14000 $g$ for $6 \mathrm{~min}$ ). Then RNA was suspended in $50 \mu \mathrm{L}$ of sterile PEPC water. RNA was quantified with a spectophotometer assuming an $\mathrm{A}_{260}$ of 1 for $40 \mu \mathrm{g} \cdot \mathrm{mL}^{-1}$. RNA was denatured by addition $(1: 3 \mathrm{vol} / \mathrm{vol})$ of a solution of $2 \%$ glutaraldehyde in Na-phosphate buffer (0.05 M, pH 7.0). The RNA samples were then diluted to obtain a concentration of $10 \mathrm{mg} \cdot \mu \mathrm{L}^{-1}$ with distilled water containing $1 \mu \mathrm{g} \cdot \mathrm{mL}^{-1}$ of polyA (Boehringer Mannheim,
$1112821)$ and $0.02 \mu \mathrm{L} \cdot \mathrm{mL}^{-1}$ of bromophenol blue.

RNA extractions were blotted on nylon membranes (Hybond N+, Amersham Pharmacia Biotech, 91400 Saclay, France) using a dot-blot apparatus (Schleicher and Schuell Co., Dassel, Germany).

Hybridization was conducted using synthetic HPLC-purified oligonucleotide probes (Eurogentec, Seraing, Belgium) 5'endlabeled with ${ }^{32} \mathrm{P}$ using a T4 kinase (Eurogentec). Four $\gamma-{ }^{32} \mathrm{P}$-labeled oligonucleotide probes were used: the probe S-D-Bact-0338a-A-18 targeting the bacterial domain, probe S-S-F.suc-0650-a-A-20 targeting Fibrobacter succinogenes, probe S-S-R.alb-0196-aA-18 targeting Ruminococcus albus and probe S-S-R.fla-1269-a-A-20 targeting Ruminococcus flavefaciens (Tab. II). The temperatures used for the stringent washes are also shown. Membranes were incubated for $1 \mathrm{~h}$ at $40^{\circ} \mathrm{C}$ with $3 \mathrm{~mL}$ of hybridization [0.9 M NaCl; 50 mM NaPO${ }_{4}, \mathrm{pH}$ 7.2; 5 mM EDTA, pH 7.0; 10× Denhart solution and $0.5 \mathrm{mg} \cdot \mathrm{mL}^{-1}$ of poly(A)] before the addition of labeled oligonucleotide to about $2 \times 10^{5} \mathrm{cpm}$ per sample dot. Incubation was continued for $8 \mathrm{~h}$ at the same temperature, and the filters were washed in SSC $1 \times(150 \mathrm{mM} \mathrm{NaCl}, 1.5 \mathrm{mM}$ sodium citrate) $-1 \%$ sodium dodecyl sulfate for $15 \mathrm{~min}$ at the temperatures indicated in Table II. Membranes were dried and exposed to a screen (Storm, Molecular Dynamics, ZI Les Bordes, CE 2318, 11 rue Madiot, 91923 Bondoufle, France). Bound probe was quantified by Image Quant Software (Molecular Dynamics). The amounts

Table II. Oligonucleotide probes used in this trial.

\begin{tabular}{llllc}
\hline Reference & Probe & Target & Sequence (5'-3') & $\mathrm{T}_{\mathrm{w}}\left({ }^{\circ} \mathrm{C}\right)$ \\
\hline Stahl et al. [24] & S-D-Bact-0338-a-A-18 & Eubacteria & GCTGCCTCCCGTAGGAGT & 54 \\
Stahl et al. [24] & S-S-F.suc-0650-a-A-20 & F. succinogenes & TGCCCCTGAACTATCCAAGA & 48 \\
Odenyo et al. [19] & S-S-R.alb-0196-a-A-18 & R. albus & GTCATGCGGCTTCGTTAT & 46 \\
Odenyo et al. [19] & S-S-R.fla-1269-a-A-20 & R. flavefaciens & TTCTCTTTGTTAATTGCCAT & 45 \\
\hline
\end{tabular}


of each cellulolytic species were expressed as percentages of the total bacterial RNA signal.

\subsection{Statistical analyses}

Variance of the data was analysed using the GLM procedure of SAS [22]. The model was:

$$
\mathrm{Y} i j k=\mu+\mathrm{D} i+\mathrm{C} j+\mathrm{P} k+\mathrm{E} i j k,
$$

where Yijk was the dependent variable for $\operatorname{diet} i$ ( $i=1$ to 2 ), for cow $j$ ( $j=1$ to 4 ), for period $k(k=1$ to 2$)$; $\mu$ was the population mean for the variable and Eijk was a random error associated with the observation $i j k$. For $\mathrm{pH}$, enzyme activities and oligonucleotide probe data, the effects of sampling time and sampling time $\times$ diet interaction were analyzed as a repeated time analysis of variance. Differences were tested using the PDIFF option and were declared significant at $P<0.1$.

\section{RESULTS}

\subsection{Ruminal pH and in situ forage degradation}

The mean ruminal $\mathrm{pH}$ was lower $(P<0.001$; data not shown) with the HB diet than with the $\mathrm{H}$ diet (6.47 vs. 6.83 , respectively). For both diets, the ruminal $\mathrm{pH}$ decreased after feeding $(P<0.001)$, but the post-prandial variation was more dramatic for the $\mathrm{HB}$ diet than for the $\mathrm{H}$ diet (0.9 vs. $0.2 \mathrm{pH}$ units, respectively; $P<0.001)$.

In situ DM effective degradability of hay decreased by 6.4 percentage units $(P<0.1$; Tab. III) between diets $\mathrm{H}$ and HB. This depressive effect of RFC on the degradability of hay was mainly related to a decrease in the degradation rate from 5.9 to $4.0 \% \cdot \mathrm{h}^{-1}(P<0.1)$. The lag time increased slightly from 3.8 to $5.3 \mathrm{~h}$ in response to barley supplementation, but this difference was not statistically significant $(P>0.1)$. Undegradable, rapid and slow fractions were comparable between the two diets $(P>0.1)$.

\subsection{Fibrolytic enzyme activities of the $\mathrm{SAB}$}

Barley supplementation systematically involved a decrease in CMCase and xylanase activities (specific and total) of the SAB before $(-1 \mathrm{~h})$ and after $(+3 \mathrm{~h})$ feeding (Time $\times$ Diet: $P>0.1$; Tab. IV). For the glycosidases, only the $\beta$-D-xylosidase activity (specific and total) and the $\beta$-D-glucosidase

Table III. In situ DM degradation of alfalfa hay in response to barley supplementation.

\begin{tabular}{lccc}
\hline Item & $\begin{array}{c}\text { Hay + straw } \\
(93 / 7)\end{array}$ & $\begin{array}{c}\text { Hay + straw + barley } \\
(33 / 7 / 60)\end{array}$ & SEM \\
\hline Undegradable fraction $(\%)$ & 20.8 & 20.3 & 0.14 \\
Rapidly degradable fraction $(\%)$ & 19.2 & 18.7 & 1.18 \\
Slowly degradable fraction $(\%)$ & 60.1 & 61.1 & 1.25 \\
Lag time (h) & 3.8 & 5.3 & 1.89 \\
Degradation constant rate $\left(\% \cdot \mathrm{h}^{-1}\right)$ & $5.9^{\mathrm{a}}$ & $4.0^{\mathrm{b}}$ & 0.45 \\
Effective degradability $(\%)$ & $42.9^{\mathrm{a}}$ & $36.5^{\mathrm{b}}$ & 1.71 \\
\hline
\end{tabular}

a, b Means with different superscripts are significantly different $(P<0.1)$. 
Table IV. Polysaccharidase activities in rumen solid-associated bacteria in response to barley supplementation.

\begin{tabular}{|c|c|c|c|c|c|c|c|}
\hline \multirow[t]{2}{*}{ Item } & \multirow{2}{*}{$\begin{array}{l}\text { Time (h) } \\
\text { /feeding }\end{array}$} & \multirow{2}{*}{$\begin{array}{l}\text { Hay + straw } \\
\quad(93 / 7)\end{array}$} & \multirow{2}{*}{$\begin{array}{c}\text { Hay }+ \text { straw +barley } \\
(33 / 7 / 60)\end{array}$} & \multirow[b]{2}{*}{ SEM } & \multicolumn{3}{|c|}{ Effect } \\
\hline & & & & & Time & Diet & Time $\times$ Diet \\
\hline \multicolumn{8}{|c|}{ Total activity, $\mu$ mol reducing sugar $\cdot \mathrm{g}^{-1} \mathrm{DM} \cdot \mathrm{h}^{-1}$} \\
\hline CMCase & $\begin{array}{l}-1 \\
+3\end{array}$ & $\begin{array}{l}33.7 \\
22.5\end{array}$ & $\begin{array}{l}27.6 \\
17.8\end{array}$ & 1.7 & $* * *$ & $*$ & NS \\
\hline Xylanase & $\begin{array}{l}-1 \\
+3\end{array}$ & $\begin{array}{l}314.7 \\
168.7\end{array}$ & $\begin{array}{l}226.4 \\
127.5\end{array}$ & 20.9 & $* * *$ & $* *$ & NS \\
\hline \multicolumn{8}{|c|}{ Specific activity, $\mu$ mol reducing sugar $\cdot \mathrm{mg}^{-1}$ protein $\cdot \mathrm{h}^{-1}$} \\
\hline CMCase & $\begin{array}{l}-1 \\
+3\end{array}$ & $\begin{array}{l}1.2 \\
1.0\end{array}$ & $\begin{array}{l}0.9 \\
0.6\end{array}$ & 0.1 & $(*)$ & $*$ & NS \\
\hline Xylanase & $\begin{array}{l}-1 \\
+3\end{array}$ & $\begin{array}{r}12.3 \\
7.3\end{array}$ & $\begin{array}{l}6.9 \\
4.3\end{array}$ & 0.8 & $* *$ & $* * *$ & NS \\
\hline
\end{tabular}

NS not significant.

(*) $P<0.1 ; * P<0.05$; ** $\mathrm{P}<0.01 ; * * * P<0.001$.

specific activity decreased in response to barley supplementation for both sampling times studied (Time $\times$ Diet: $P>0.1$; Tab. V). Irrespective of the diet considered, solid-associated bacteria fibrolytic activities (total or specific) of all enzymes studied (polysaccharidases, glycosidases) were significantly higher before $(-1 \mathrm{~h})$ than after feeding $(+3 \mathrm{~h})$.

\subsection{Cellulolytic bacterial community in the $\mathrm{SAB}$}

Total bacterial rRNA concentration was comparable between diets before feeding but higher with the HB diet than with the $\mathrm{H}$ diet $3 \mathrm{~h}$ postfeeding (Time $\times$ Diet: $P<0.05$; Tab. VI). A comparable effect of the diet was observed 3 hours after feeding on the rRNA concentration of $R$. albus (Time: $P<0.05$; Time $\times$ Diet: $P<0.1$; Tab. VI), but no diet effect was observed on the rRNA concentration of $F$. succinogenes and $R$. flavefaciens $(P>0.1$; Tab. VI).

The relative population size of the cellulolytic bacterial community was comparable between diets (Diet, Time $\times$ Diet: $P>0.1$; Tab. VII) and represented an average of $17 \%$ of the total bacterial rRNA. No effect of the diet was observed on the proportion of the 3 individual cellulolytic bacteria studied $(P>0.1)$. The relative population size of $R$. albus (\% total bacterial rRNA) was systematically much greater than that of either $R$. flavefaciens and $F$. succinogenes and represented on average for both diets $65 \%$ of the cellulolytic bacterial rRNA examined.

\section{DISCUSSION}

The supplementation of the forage diet with barley depressed the DM degradability of hay in the nylon bag, and was related to a decrease in the forage degradation rate. The depressive effect of readily fermentable carbohydrates on ruminal forage degradation is well known. And, in other studies [6, 14, 18], decreases in forage degradability with high-concentrate supplementation was also associated with a decrease in the degradation 
Table V. Glycosidase activities in rumen solid-associated bacteria in response to barley supplementation.

\begin{tabular}{|c|c|c|c|c|c|c|c|}
\hline \multirow[t]{2}{*}{ Item } & \multirow{2}{*}{$\begin{array}{l}\text { Time (h) } \\
\text { /feeding }\end{array}$} & \multirow{2}{*}{$\begin{array}{c}\text { Hay }+ \text { straw } \\
(93 / 7)\end{array}$} & \multirow{2}{*}{$\begin{array}{c}\text { Hay }+ \text { straw +barley } \\
(33 / 7 / 60)\end{array}$} & \multirow[b]{2}{*}{ SEM } & \multicolumn{3}{|c|}{ Effect } \\
\hline & & & & & Time & Diet & Time $\times$ Diet \\
\hline \multicolumn{8}{|c|}{ Total activity, $\mu \mathrm{mol} p$-nitrophenol. $\mathrm{g}^{-1} \mathrm{DM} \cdot \mathrm{h}^{-1}$} \\
\hline$\alpha$-L-arabinofuranosidase & -1 & 45.6 & 51.7 & \multirow{2}{*}{4.1} & \multirow{2}{*}{$* *$} & \multirow{2}{*}{ NS } & \multirow{2}{*}{ NS } \\
\hline & +3 & 30.2 & 32.6 & & & & \\
\hline \multirow[t]{2}{*}{$\beta$-D-glucosidase } & -1 & 56.0 & 60.2 & \multirow{2}{*}{3.9} & \multirow{2}{*}{$*$} & \multirow{2}{*}{ NS } & \multirow{2}{*}{ NS } \\
\hline & +3 & 51.7 & 43.5 & & & & \\
\hline \multirow[t]{2}{*}{$\beta$-D-xylosidase } & -1 & 108.8 & 81.5 & \multirow[t]{2}{*}{9.1} & \multirow[t]{2}{*}{$* *$} & \multirow[t]{2}{*}{$*$} & \multirow[t]{2}{*}{ NS } \\
\hline & +3 & 71.6 & 51.9 & & & & \\
\hline \multicolumn{8}{|c|}{ Specific activity, $\mu \mathrm{mol} p$-nitrophenol $\cdot \mathrm{mg}^{-1}$ protein $\mathrm{h}^{-1}$} \\
\hline \multirow[t]{2}{*}{$\alpha$-L-arabinofuranosidase } & -1 & 1.43 & 1.56 & \multirow{2}{*}{0.08} & \multirow{2}{*}{$* * *$} & \multirow{2}{*}{ NS } & \multirow{2}{*}{ NS } \\
\hline & +3 & 1.03 & 1.06 & & & & \\
\hline \multirow[t]{2}{*}{$\beta$-D-glucosidase } & -1 & 1.79 & 1.77 & \multirow{2}{*}{0.09} & \multirow{2}{*}{$* *$} & \multirow{2}{*}{$(*)$} & \multirow{2}{*}{ NS } \\
\hline & +3 & 1.64 & 1.32 & & & & \\
\hline \multirow[t]{2}{*}{$\beta$-D-xylosidase } & -1 & 3.55 & 1.97 & \multirow{2}{*}{0.25} & \multirow{2}{*}{$* *$} & \multirow{2}{*}{$* *$} & \multirow{2}{*}{ NS } \\
\hline & +3 & 2.30 & 1.60 & & & & \\
\hline
\end{tabular}

NS not significant.

(*) $P<0.1$; * $P<0.05$; ** $\mathrm{P}<0.01$; *** $P<0.001$.

Table VI. Solid-associated cellulolytic bacterial community in response to barley supplementation.

\begin{tabular}{|c|c|c|c|c|c|c|c|}
\hline \multirow[t]{2}{*}{ Item } & \multirow{2}{*}{$\begin{array}{l}\text { Time (h) } \\
\text { /feeding }\end{array}$} & \multirow{2}{*}{$\begin{array}{l}\text { Hay + straw } \\
\quad(93 / 7)\end{array}$} & \multirow{2}{*}{$\begin{array}{c}\text { Hay }+ \text { straw +barley } \\
(33 / 7 / 60)\end{array}$} & \multirow[b]{2}{*}{ SEM } & \multicolumn{3}{|c|}{ Effect } \\
\hline & & & & & Time & Diet & Time $\times$ Diet \\
\hline $\begin{array}{l}\text { Total bacterial rRNA, } \\
\mu \mathrm{g} \cdot \mathrm{g}^{-1} \mathrm{DM}\end{array}$ & $\begin{array}{l}-1 \\
+3\end{array}$ & $\begin{array}{l}2474 \\
1466\end{array}$ & $\begin{array}{l}2272 \\
2480\end{array}$ & 246 & $(*)$ & (*) & $*$ \\
\hline $\begin{array}{l}\text { Sum of the } 3 \text { cellulolytic } \\
\text { bacterial rRNA, } \mu \mathrm{g} \cdot \mathrm{g}^{-1} \mathrm{DM}\end{array}$ & $\begin{array}{r} \\
-1 \\
+3\end{array}$ & $\begin{array}{l}369 \\
200\end{array}$ & $\begin{array}{l}349.8 \\
610.8\end{array}$ & 86 & $*$ & $(*)$ & $* * *$ \\
\hline $\begin{array}{l}\text { F. succinogenes } \mathrm{rRNA} \text {, } \\
\mu \mathrm{g} \cdot \mathrm{g}^{-1} \mathrm{DM}\end{array}$ & $\begin{array}{l}-1 \\
+3\end{array}$ & $\begin{array}{l}99.8 \\
44.8\end{array}$ & $\begin{array}{l}80.6 \\
51.6\end{array}$ & 8 & $* * *$ & NS & $(*)$ \\
\hline R. albus $\mathrm{rRNA}, \mu \mathrm{g} \cdot \mathrm{g}^{-1} \mathrm{DM}$ & $\begin{array}{l}-1 \\
+3\end{array}$ & $\begin{array}{l}184.4 \\
113.4\end{array}$ & $\begin{array}{l}203.4 \\
502.8\end{array}$ & 88 & $*$ & $*$ & $(*)$ \\
\hline $\begin{array}{l}\text { R. flavefaciens rRNA, } \\
\mu \mathrm{g} \cdot \mathrm{g}^{-1} \mathrm{DM}\end{array}$ & $\begin{array}{l}-1 \\
+3\end{array}$ & $\begin{array}{l}84.8 \\
41.8\end{array}$ & $\begin{array}{l}65.8 \\
56.4\end{array}$ & 16 & $* *$ & NS & $*$ \\
\hline
\end{tabular}

NS not significant.

(*) $P<0.1$; $* P<0.05$; ** $\mathrm{P}<0.01$; *** $P<0.001$. 
Table VII. rRNA percentage of each bacterial species relative to total bacterial rRNA in response to barley supplementation.

\begin{tabular}{|c|c|c|c|c|c|c|c|}
\hline \multirow[t]{2}{*}{ Item } & \multirow{2}{*}{$\begin{array}{l}\text { Time }(\mathrm{h}) \\
\text { /feeding }\end{array}$} & \multirow{2}{*}{$\begin{array}{l}\text { Hay + straw } \\
\quad(93 / 7)\end{array}$} & \multirow{2}{*}{$\begin{array}{c}\text { Hay }+ \text { straw +barley } \\
(33 / 7 / 60)\end{array}$} & \multirow[b]{2}{*}{ SEM } & \multicolumn{3}{|c|}{ Effect } \\
\hline & & & & & Time & Diet & Time $\times$ Diet \\
\hline $\begin{array}{l}\text { Sum of the } 3 \text { cellulolytic } \\
\text { bacterial rRNA }\end{array}$ & $\begin{array}{l}-1 \\
+3\end{array}$ & $\begin{array}{l}14.9 \\
13.6\end{array}$ & $\begin{array}{l}15.4 \\
24.7\end{array}$ & 5.1 & NS & NS & NS \\
\hline F. succinogenes rRNA & $\begin{array}{l}-1 \\
+3\end{array}$ & $\begin{array}{l}4.0 \\
3.1\end{array}$ & $\begin{array}{l}3.5 \\
2.1\end{array}$ & 0.8 & NS & NS & NS \\
\hline R. albus rRNA & $\begin{array}{l}-1 \\
+3\end{array}$ & $\begin{array}{l}7.5 \\
7.6\end{array}$ & $\begin{array}{r}9.0 \\
20.3\end{array}$ & 4.0 & NS & NS & NS \\
\hline R. flavefaciens rRNA & $\begin{array}{l}-1 \\
+3\end{array}$ & $\begin{array}{l}3.4 \\
2.9\end{array}$ & $\begin{array}{l}2.9 \\
2.3\end{array}$ & 0.9 & NS & NS & NS \\
\hline
\end{tabular}

NS not significant.

rate. Our results confirmed that at a constant feeding level, the reduced digestion of the plant cell wall in the rumen in response to RFC supplementation may be due more to the reduced digestive capacity of the rumen microbial ecosystem than to the reduced retention time of forage particles [14].

Since the solid-associated bacterial community is known to constitute the greatest and the most active rumen microbial community with regards to microbial mass and fibrolytic activities [13, 15, 30], enzyme and community structure were preferentially assessed in this population.

Barley supplementation induced a decrease in total and specific polysaccharidase activities (CMCase, xylanase) of the $\mathrm{SAB}$. The glycosidase activities were not systematically depressed by barley supplementation confirming that such activities are widely represented in the rumen microbial ecosystem and are less specific to the fibrolytic microorganisms than the polysaccharidase activities $[18,25]$. So, the depression in the in situ forage degradation rate may be related to a reduction of CMCase and xylanase activities as a result of barley supplementation of the SAB [5, 13, 18]. Two hypotheses may be proposed to explain the negative effect of RFC on the fibrolytic enzyme activities of bacteria adhering to plant material: (1) a catabolite regulation of fibrolytic enzymes involving end products of starch degradation barley $[4,26]$ and/or a low ruminal $\mathrm{pH}$ characterizing the mixed diet $[5,13]$ as observed in the present work; (2) a modification of the bacterial colonization and/or species associated with particles. Originally, our work was also to detect and quantify the selected cellulolytic bacterial species associated with plant material by a molecular approach, such as the 16S-rRNA-targeted oligonucleotide probes. This technique allows the analysis of the microbial populations to a degree that is not possible by classical microbial culture techniques [1,21, 23].

The fact that the colonization of feed particles by the bacterial community was not affected in the presence of barley is in agreement with other data $[8,10,27]$ mentioning that the number of cellulolytic bacteria, determined by the classical culture-based 
technique, remained stable when grain feeding increased. In a previous work, we also reported that the density of microorganisms adherent to particles, estimated with ${ }^{15} \mathrm{~N}$ as a microbial marker, was similar on diets containing from $0 \%$ to $35 \%$ barley diets [13]. The increase of $R$. albus concentration in the presence of barley was not noted by Vander Linden et al. [27]. In the contrast, these authors observed that the concentrations of $R$. flavefaciens increased in sheep when the percentage of grains increased from 0 to $40 \%$ in the diet. In our study, the 3 dominant cellulolytic bacteria in the ruminal ecosystem were studied but it cannot be excluded that other cellulolytic bacteria or fungi species were not modified by barley supplementation. However, it has been reported that the number of fungi present in the bovine rumen remains relatively constant for diets with $0 \%$ to $80 \%$ concentrate [12].

No effect of sampling time and diet was found on the proportions of the cellulolytic bacterial population and of the 3 different cellulolytic species associated with plant material. In agreement with this, the relative proportions of the different cellulolytic bacterial species, determined with the oligonucleotide probes, remain fairly constant at several times after feeding for steers fed orchardgrass [2] or for sheep fed a diet containing $60 \%$ barley [16]. Concerning the effect of the diet on the relative population size of the cellulolytic bacterial community, only one study dealing with this aspect is available in the literature [29]. The authors assessed the relative proportion of the 3 cellulolytic bacterial species in the rumen of lactating cows fed different diets varying in the amounts (24 vs. 32\%) and sources of forages (alfalfa silage vs. corn silage). And, despite large differences in ruminal fermentative parameters ( $\mathrm{pH}, \mathrm{AGV}$ ) from individual cows, the relative population sizes of individual cellulolytic species showed few consistent differences according to the diets for individual cows.
The range of post-feeding variations in the rRNA concentrations of the cellulolytic bacterial community differed between diets. The bacterial concentration of the 3 cellulolytic species studied decreased systematically after feeding the forage diet. With the barley supplemented diet, the post-feeding decrease in rRNA concentration of $F$. succinogenes and $R$. flavefaciens was less marked than with the $\mathrm{H}$ diet. In our study, animals were restrictively fed and ingested the same quantities of DM $\left(7 \mathrm{~kg} \cdot \mathrm{d}^{-1}\right)$ for both diets, but the quantities of fiber ingested were two fold lower for the mixed diet $\left(1.2 \mathrm{~kg} \cdot \mathrm{d}^{-1}\right)$ than for the hay diet $\left(2.3 \mathrm{~kg} \cdot \mathrm{d}^{-1}\right)$. So, it could be supposed that the feed dilution effect on bacterial concentration in response to feed intake was less important with the $\mathrm{HB}$ diet than with the $\mathrm{H}$ diet because of the lower fiber pool ingested with the HB diet.

In contrast to the two other cellulolytic bacteria species studied, rRNA concentration of $R$. albus tended to increase after feeding the HB diet. This apparently different answer of $R$. albus may be related to the large variability (high SEM) in the response to the probe specific for $R$. albus and not to the representativeness of the rumen content samples. Considerable differences in the responses of $R$. albus and $R$. flavefaciens strains to their specific probes have already been reported [19, 29]. Different strains of a given microbial species may exist within and between animals [29].

The relative size of the cellulolytic bacterial population examined represented a mean of $17 \%$ of the total rumen bacterial community for the two diets. This value is higher than those reported in other studies for ruminal contents of sheep $[7,16,17]$ or cows [29] where the relative population size of the three main cellulolytic species accounted for 4 to $9 \%$ of the total bacterial rRNA signal. In the present work, the relative population size of the Ruminococci (including $R$. albus and $R$. flavefaciens) were much greater than that of $F$. succinogenes. In 
agreement with our results, Weimer et al. [29] reported a higher proportion of the 2 Ruminococci compared to $F$. succinogenes in the ruminal microbial ecosystem of dairy cows, with $R$. albus as the dominant cellulolytic bacterial species (65\% of the cellulolytic bacterial rRNA). In contrast in sheep, $F$. succinogenes was the main cellulolytic species or in equal proportion with the Ruminococci $[16,17]$. These results suggest that the rumen microbial ecosystem of cows and sheep are characterized by different fibrolytic bacterial profile, but this needs to be confirmed.

\section{CONCLUSION}

It appears that the negative effect of the RFC on fiber degradation rate is not due to a modification of the balance of the cellulolytic bacterial species colonizing the plant material, but only to a specific decrease in fibrolytic activity of the solid-associated microorganisms. Fibrolytic enzyme activities of solid-associated microorganisms may be an effective way to assess the differences between various environments in relation with ruminal fiber digestion. Acting on fibrolytic activity of the rumen microbial ecosystem is a first step in the optimization of plant cell wall digestion, mainly when the digestion potential is not attained because digestion is compromised.

\section{REFERENCES}

[1] Alexander M.A., Microbial communities and interactions: a prelude, in: Hurst C.J., Knudsen G.R., McInerney M.J., Stetzenbach L.D., Walter M.P. (Eds.), Manual of Environmental Microbiology, Am. Soc. Microbiol, Washington, DC, 1997, pp. 5-13.

[2] Briesacher S.L., May T., Grigsby K.N., Kerley M.S., Antony R.V., Paterson J.A., Use of DNA Probes to monitor nutritional effects on ruminal prokaryotes and Fibrobacter succinogenes S85, J. Anim. Sci. 70 (1992) 289-295.

[3] Dhanoa M.C., On the analysis of dracon bag data for low degradability feeds, Grass For. Sci. 43 (1988) 441-444.
[4] Huang L., Forsberg C.W., Cellulose digestion and cellulase regulation and distribution in Fibrobacter succinogenes subsp. Succinogenes S85, Appl. Environ. Microbiol. 56 (1990) 1221-1228

[5] Huhtanen P., Khalili H., The effect of sucrose supplements on particle-associated carbomethylcellulase (EC 3.2.1.4) and xylanase (EC 3.2.1.8) activities in cattle given grass silage based diets, Br. J. Nutr. 67 (1992) 245-255.

[6] Kennedy D.W., Bunting L.D., Effects of starch on ruminal fermentation and detergent fibre digestion in lambs fed bermudagrass hay, Anim. Feed Sci. Technol. 36 (1992) 91-100.

[7] Krause D.O., Darlymple B.P., Smith W.J., Mackie R.I., McSweeney C.S., 16S rDNA sequencing of Ruminococcus albus and Ruminococcus flavefaciens: design of a signature probe and its application in adult sheep, Microbiol. 145 (1999) 1787-1807.

[8] Leedle J.A.Z., Barshun K., Hespell R.B., Postprandial trends in estimated ruminal digesta polysaccharides and their relation to changes in bacterial groups and ruminal fluid characteristics, J. Anim. Sci. 62 (1986) 789-803.

[9] Lever M., Carbohydrate determination with 4-hydroxybenzoic acid hydrazide (PAHßAH): Effect of bismuth on the reaction, Anal. Biochem. 81 (1977) 21-27.

[10] Mackie R.I., Gilchrist F.M.C., Roberts A.M., Hannah P.E., Schwartz H.M., Microbiological and chemical changes in the rumen during the stepwise adaptation of sheep to high concentrate diets, J. Agri. Sci. (Camb.). 90 (1978) 241-254.

[11] McAllister T.A., Bae H.D., Jones G.A., Cheng K.J., Microbial attachment and feed digestion in the rumen, J. Anim. Sci. 72 (1994) 3004-3018.

[12] McAllister T.A., Hristov A., Wang Y., Recent advances/current understanding of factors impacting barley utilization by ruminants, Proceedings of the 36th Annual Pacific Northwest Animal Nutrition Conference, 2001, pp. 93-114.

[13] Martin C., Michalet-Doreau B., Variations in mass and enzyme activity of rumen microorganisms: effect of barley and buffer supplements, J. Sci. Food Agric. 67 (1995) 409-415.

[14] Martin C., Michalet-Doreau B., Influence of barley and buffer supplements on quantitative aspects of ruminal fiber digestion of cows, Arch. Anim. Nutr. 49 (1996) 203-211.

[15] Martin C., Michalet-Doreau B., Fonty G., Williams A.G., Postprandial variations in the activity of polysaccharide-degrading enzymes of fluid- and particle-associated ruminal microbial populations, Curr. Microbiol. (1993) 223-228.

[16] Michalet-Doreau B., Fernandez I., Fonty G., A comparison of enzymatic and molecular approaches to characterize the cellulolytic microbial ecosystems of the rumen and the cecum, J. Anim. Sci., in press. 
[17] Michalet-Doreau B., Fernandez I., Peyron C., Millet L., Fibrolytic activities and cellulolytic bacterial community structure in the solid and liquid phases of rumen contents, Reprod. Nutr. Dev. 41 (2001) 187-194.

[18] Nozière P., Besle J.M., Martin C., MichaletDoreau B., Relation between in situ forage degradation rate and fibrolytic activity of solid associated microorganisms in the rumen, J. Sci. Food Agric. 72 (1996) 235-242.

[19] Odenyo A.A., Mackie R.I., Stahl D.A., White B.A., The use of $16 \mathrm{~S}$ rRNA-targeted oligonucleotide probes to study competition between fibrolytic bacteria: pure culture studies with cellulose and alkaline peroxide-treated wheat straw, Appl. Environ. Microbiol. 60 (1994) 3688-3696.

[20] Pierce J., Suelter C.H., An evaluation of Coomassie brilliant blue G-250 dye-binding method for quantitative protein determination, Anal. Biochem. 81 (1977) 478-480.

[21] Raskin L., Capman W.C., Sharp R., Poulsen L.K., Stahl D.A., Molecular ecology of gastrointestinal ecosystems, in: Mackie R.I., White B.A., Isaacson R.E. (Ed.), Gastrointestinal Tract Microbiology, Chapman and Hall, New York, NY, 1997, pp. 243-298.

[22] SAS, SAS/STAT ${ }^{\circledR}$ User's Guide: Statistics (Release 6.03). SAS Inst. Inc., Cary, NC, 1988.

[23] Stahl D.A., Application of phylogenetically based hybridization probes to microbial ecology, Appl. Environ. Microbiol. 54 (1995) 1079-1084.

[24] Stahl D.A., Flesher B., Mansfield H.R., Montgomery L., Use of phylogenetically based hybridization probes for studies of rumen microbial ecology, Appl. Environ. Microbiol. 54 (1988) 1079-1084.

[25] Stewart C.S., Bryant M.P., The rumen bacteria, in: Hobson P.N. (Ed.), The rumen microbial ecosystem, Elsevier Applied Science, London and New York, 1988, pp. 21-75.

[26] Teather R.M., Ohmiya K., Molecular genetics of rumen cellulase systems, in: Tsuda T., Saski Y., Kawashima R. (Eds.), Physiological aspects of digestion and metabolism in ruminants, Sendai, Japan, Academic Press, Inc., 1991, pp. 701-717.

[27] Van der Linden Y., Van Gylswyk N.O., Schwartz H.M., Influence of supplementation of corn stover with corn grain on the fibrolytic bacteria in the rumen of sheep and their relation to the intake and digestion of fiber, J. Anim. Sci. 59 (1984) 772-783.

[28] Vérité R., Chapoutot P., Michalet-Doreau B. Peyraud J.L., Poncet C., Révision du système des protéines digestibles dans l'intestin (PDI), Bull. Tech. C.R.Z.V. Theix 70 (1988) 19-34.

[29] Weimer P.J., Waghorn G.C., Odt C.L., Mertens D.R., Effect of diet on populations of three species of ruminal cellulolytic bacteria in lactating diary cows, J. Dairy Sci. 82 (1999) $122-134$.

[30] Williams A.G., Withers S.E., Strachan N.H., Postprandial variations in the activity of polysaccharide-degrading enzymes in microbial populations from the digesta solids and liquor fractions of rumen contents, J. Appl. Bacteriol. 66 (1989) 15-26. 